Int. J. Environ. Res. Public Health 2006, 3(4), 348-354

International Journal of

Environmental Research and Public Health

ISSN 1661-7827

www.jorjerph.org

(c) 2006 by MDPI

\title{
Photoirradiation of Polycyclic Aromatic Hydrocarbons with UVA Light - A Pathway Leading to the Generation of Reactive Oxygen Species, Lipid Peroxidation, and DNA Damage
}

\author{
Hongtao Yu ${ }^{1}$, Qingsu Xia ${ }^{2}$, Jian Yan ${ }^{1}$, Diogenes Herreno-Saenz ${ }^{3}$, Yuh-Shen Wu ${ }^{4}$, I-Wah Tang ${ }^{2}$, and Peter P. Fu ${ }^{2 *}$ \\ ${ }^{1}$ Department of Chemistry, Jackson State University, Jackson, MS 39217, USA \\ ${ }^{2}$ National Center for Toxicological Research, Jefferson, AR 72079, USA \\ ${ }^{3}$ Department of Pharmacology and Toxicology, School of Medicine, University of Puerto Rico, San Juan, Puerto Rico 00935 \\ ${ }^{4}$ Hung Kuang University, Sha-Lu, Taichung, Taiwan, ROC \\ *Correspondence to: Dr. Hongtao Yu, Email: hongtao.yu@jsums.edu; Dr. Peter P. Fu, E-mail: pfu@nctr.fda.gov
}

Received: 12 July 2005 / Accepted: 20 August 2006 / Published: 31 December 2006

\begin{abstract}
Polycyclic aromatic hydrocarbons (PAHs) are a class of genotoxic environmental contaminants. We have long been interested in determining the mechanisms by which PAHs induce genotoxicity. Although the metabolic activation of PAHs leading to biological activities has been well studied, the photo-induced activation pathway has seldom reported. In this paper, we review the study of photoirradiation of PAHs with UVA irradiation results in (i) cytotoxicity and DNA damage (ii) DNA single strand cleavage; (iii) formation of 8-hydroxy-2'-deoxyguanosine adduct $(8-\mathrm{OHdG})$, and (iv) formation of lipid peroxidation. Evidence has been shown that these photobiological activities are mediated by reactive oxygen species (ROS).
\end{abstract}

Keywords: Polycyclic aromatic hydrocarbons (PAHs), photoirradiation, lipid peroxidation, DNA damage, 8-OHdG

\section{Introduction}

Polycyclic aromatic hydrocarbons (PAHs) are a class of genotoxic environmental contaminants [1-6]. PAHs are formed from incomplete combustion of fossil fuels during both natural events and human activities $[3,5,7,8]$. Being ubiquitous in the environment, PAHs are thought to induce tumors, primarily in the lungs, bladder and in the skin [1, 3-5, 7]. The International Agency for Research on Cancer, the United States Environmental Protection Agency, and the National Toxicology Program have classified some PAHs as probable human carcinogens [9-11]. Study of the mechanisms by which PAHs induce cancers has been the most intensive in the field of chemical carcinogenesis. The tumorigenicity and the metabolic activation pathways of PAHs have been well-studied and many books and review articles have reported on the study of carcinogenesis by PAHs [1, 3, 6, 9, 10].

It is established that PAHs require metabolic activation in order to exert biological activities, including carcinogenicity [3]. During the last several decades, study of the mechanisms by which PAHs induce tumors in experimental animals has been one of the most extensive in the field of chemical carcinogenesis [3, 6, 12]. To date, three metabolic activation pathways in vivo have been determined, namely; metabolism into bay-region diol epoxides, radicalcation intermediates, and quinones [3, 13-16] (Figure 1). Among the three activation pathways, formation of diol epoxide-derived DNA adducts is the principal metabolic activation pathway leading to cancer initiation (Figure 1). All these pathways result in binding of the ultimate metabolites with cellular DNA to form exogenous DNA adducts leading to cancer formation. Penning et al. [16] have also found that the activation pathway that forms quinone also involves the generation of reactive oxygen species (ROS) and leads to the formation of endogenous DNA adducts.

Another pathway that activates PAHs to induce various toxicities is light activation. PAHs generally absorb UV light and some also absorb visible light. Upon light absorption, PAHs are excited to their upper energy states that can initiate a series of excited state reactions leading to ROS and other reactive intermediates that can damage DNA, protein, and cell membrane, leading to acute toxicity and genotoxicity. 
1. Diolepoxide Formation

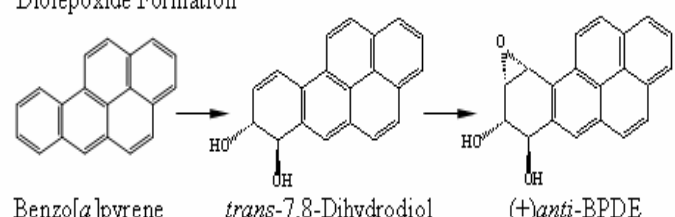

Benzo[a]pyrene trans-7,8-Dihydrodiol

(+)anti-BPDE

2. Formation of Radical Cations

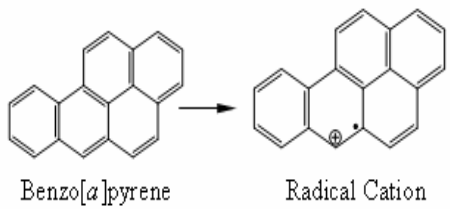

3. Benzo[a]pyrene-7,8-Quinone Formation

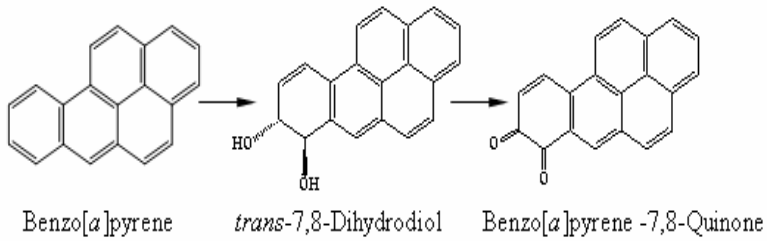

Figure 1: The three principal metabolic activation pathways of benzo[a]pyrene leading to tumour initiation.

Skin is the largest body organ in humans and a principal target organ on cancer induced by PAHs. Phototoxicity of PAHs has been recognized more than seventy years ago [1722]. It has also been reported that upon light irradiation, PAHs exhibit phototoxicity [17]. Thus, photoirradiation of PAHs can be an activation pathway and may play an important role on skin cancer [23-26]. However, this pathway has received much less attention. In the present review, we report that photoirradiation of PAHs can result in cytotoxicity, mutagenicity, DNA damage, and induction of lipid peroxidation.

\section{PAH Photoirradiaion Leading to Toxicity and Genotoxicity}

The photochemical and phototoxic activities of PAHs were reviewed in 2002 [17]. The review of the effects of near UV radiation on the toxic effects of PAHs in animals and plants was reported in 1996 [27]. Generally, the resulting reactive species generated due to photo-excitation can damage a variety of cellular tissues, with DNA as the principal target leading to genotoxicity [17, 27]. The possible DNA damages include: (i) Single strand cleavage, (ii) Double strand cleavage, (iii) Deletion of a base (depurination/depyrimidation), (iv) Oxidation of guanine to 8-hydroxy- or 8-oxo-guanine, (v) Thymine-thymine dimer formation, (vi) DNA covalent adducts, (vii) DNADNA cross-links, and (viii) DNA-protein cross-links. To date, several types of DNA damages caused by photoirradiation of PAHs have been reported, including the formation of PAH-DNA covalent adducts, DNA single strand cleavage, and formation of oxidative product 8- hydroxyguanine. When photoirradiation is performed in the presence of lipid molecules, induction of lipid peroxidation has also been determined.

\section{Theoretical and Mechanistic Consideration}

\section{Formation of ROS}

The mechanisms leading to phototoxicity by PAHs have been studied [28-42]. PAHs that contain three or more aromatic rings can absorb UVA $(320-400 \mathrm{~nm})$ and visible (> $400 \mathrm{~nm}$ ) light. The resulting excited PAHs can act as sensitizers to transfer energy or one electron to molecular oxygen to form reactive oxygen species (ROS) [17]. It can also react with other molecules to generate reactive intermediates. Both ROS and the reactive intermediates can damage cellular constituents such as cell membrane, nucleic acids, or proteins, resulting in acute toxicity and genotoxicity including carcinogenicity, mutgenicity, and teratology.

\section{Reactive PAH Intermediates}

It has been found that upon light irradiation, anthracene, benz[a]anthracene (BA), pyrene, 5-methylbenz[a]anthracene, 7,12-dimethyl-BA (DMBA), and benzo[a]pyrene react with oxygen to form endoperoxides as intermediates and the corresponding quinones as the end products [17,43-50]. These results indicate that quinones are the stable end photoproducts of PAH light irradiation. It is proposed that the oxy-radical intermediate is formed and is responsible for DNA damage caused by concomitant exposure to benzo[a]pyrene and UV light [51]. Consequently, it is highly possible that the radical intermediates leading to the quinone formation are the species capable of causing DNA damage as well as inducing lipid peroxidation.

Multiple photoproducts can also be formed in some cases. For example, photoirradiation of DMBA with UVA light forms a series of photoproducts, including 7,12endoperoxide, 7-hydroxymethyl-12-MBA, DMBA-7,12quinone, 12-hydroxymethyl-7-MBA, 7-formyl-12-MBA, and 12-formyl-7-MBA [50].

\section{Photocytotoxicity}

PAHs are generally more toxic when exposed to light than without light irradiation. The phototoxicity can be more than 100-fold higher than their toxicity in the absence of light irradiation [52,53]. Yan et al. [54] found that benz $[a]$ anthracene, benzo $[a]$ pyrene, anthracene, benzo[ghi]perylene, indeno[1,2,3-cd]pyrene, and pyrene are highly phototoxic in Salmonella typhimurium TA102 concomitantly irradiated with UVA light.

\section{Photomutagenicity}

Azulene is a non-alternate hydrocarbon, consisting of an unsaturated seven member ring fused with an 
unsaturated five member ring (Figure 2). It absorbs red light in the visible region (600 nm band) for the first excited state transition and UVA light (330 $\mathrm{nm}$ band) for the second excited state transition and produces a beautiful blue color in aqueous solutions [55]. This is drastically different from naphthalene, which absorbs light only in the UVB region $(<315 \mathrm{~nm})$.
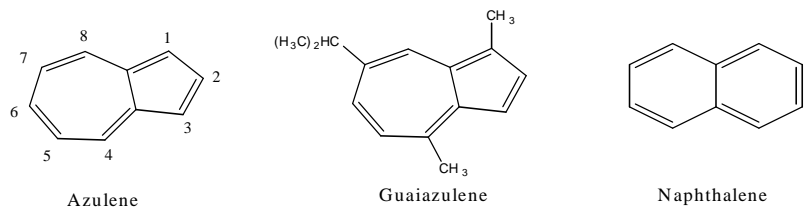

Figure 2: Chemical structures of azulene, guaiazulene and naphthalene

Azulene and its alkyl derivative guaiazulene, 1,4dimethyl-7-isopropylazulene and its structural isomer naphthalene (Figure 2) are the simplest PAHs. Azulene and its derivative are popular ingredients in beauty, cosmetic, skin, and body care products [56]. The photomutagenicity of azulene and guaiazulene in Salmonella typhimurium TA98, TA100 and TA102 was determined by irradiation with UVA and visible light. Both azulene and gauiazulene exhibited photomutagenicity on TA102. Azulene was photomutagenic when irradiated by UVA light, visible light, or a combination of UVA and visible light [56]. At the same time, naphthalene is not photomutagenic or acutely phototoxic. The difference in toxicity is due primarily to the light absorption. While azulene and guaiazulene absorbs UVA and visible light, naphthalene does not.

The photomutagenicity of sixteen PAHs, all on the US EPA Priority Pollutant List, was studied [56]. Concomitant exposing the Salmonella typhimurium bacteria strain TA102 to one of the PAHs and light $\left(1.15 \mathrm{~J} / \mathrm{cm}^{2} \mathrm{UVA}+2.1 \mathrm{~J} / \mathrm{cm}^{2}\right.$ visible $)$ without the metabolic enzyme mix S9, strong mutagenic response is observed for anthracene, benz $[a]$ anthracene, benzo[ $g h i]$ perylene, benzo[ $a]$ pyrene, indeno[1,2,3-cd]pyrene, and pyrene. Under the same conditions, acenaphthene, acenaphthylene, benzo[ $k]$ fluoranthene, chrysene, and fluorene are weakly photomutagenic. Benzo $[b]$ fluoranthene, fluoranthene, naphthalene, phenanthrene, and dibenz $[a, h]$ anthracene are not photomutagenic. These results indicate that PAHs can be activated by light and become mutagenic in Salmonella TA102 bacteria. It has been found that DMBA is phototoxic in bacteria as well as in animal or human cells and photomutagenic in Salmonella typhimurium strain TA102 [49].

\section{Formation of DNA Adducts}

In 1964, Ts'O and Lu first reported that irradiation of benzo $[a]$ pyrene by light $(>300 \mathrm{~nm}$ or $>340 \mathrm{~nm}$ ) induced the formation of covalent DNA adducts, and proteins and cell membranes can be important photo-damage targets for PAH-DNA adducts [57]. Since then, it was found that irradiation on the mixture of dibenz $[a, c]$ anthracene or dibenz $[a, h]$ anthracene with DNA in aqueous solutions also formed covalent DNA adducts [17]. Photoirradiation of anthracene in human skin, human serum albumin, or monkey kidney epithelial cells all generated DNA adducts [39, 58].

Photoirradiation of DMBA in the presence of calf thymus DNA followed by ${ }^{32} \mathrm{P}$-postlabeling/TLC indicated that multiple DNA adducts were formed [49]. Comparison of the DNA adduct profiles indicates that the DNA adducts formed from photo-irradiation are different from the DNA adducts formed due to the reaction of DMBA metabolites with DNA. These results suggest that photoirradiation of DMBA can lead to genotoxicity through activation pathways different from those by microsomal metabolism of DMBA [49].

\section{Light-Induced DNA Single Strand Cleavage by PAHs}

It was reported that irradiation of benzo $[a]$ pyrene in the presence of PM2 DNA caused the cleavage of the supercoiled form to the relaxed circular form [51]. DMBA exposed to near UV light also caused DNA single strand cleavage [59]. Kagan et al determined that anthracene [40] can cause pBR322 DNA single strand cleavage.

A systematic light-induced DNA single strand cleavage study has been carried out for various PAHs using UVA light and $\Phi X 174$ plasmid DNA [47, 60-64]. The extent of DNA single strand cleavage was dependent on both light and PAH doses. Therefore, by fixing the light dose at $170 \mathrm{~J} / \mathrm{cm}^{2}$ ( $1 \mathrm{~h}$ irradiation), a relative DNA photocleavage efficiency indicator, $\mathrm{C}_{25}$, the concentration at which $25 \%$ of the original supercoiled DNA is converted into relaxed, open circular DNA upon the combination of a PAH and light irradiation, is determined. The $\mathrm{C}_{25}$ can be used to compare relative DNA photocleavage efficiency for various PAHs. The smaller the $\mathrm{C}_{25}$ values, the more efficient is a $\mathrm{PAH}$ toward DNA single strand cleavage.

The $\mathrm{C}_{25}$ values depend on both (i) the structure of the PAHs and (ii) the ring size and arrangement of the rings. A larger ring does not necessarily mean higher DNA photocleavage efficiency. The three-ring anthrancene is a stronger DNA photocleaver than the four-ring pyrene, but is similar to the four-ring chrysene and BA and the five ring benzo[a]pyrene [62]. Metabolic products of benzo $[a]$ pyrene are all more efficient in causing DNA photocleavage [64]. As shown in Table 1, methyl substitution on BA has an interesting effect on their DNA photocleavage efficiency. Methyl substitution at 4, 5, 6, 8, 9,10 positions does not affect the photocleavage efficiency for BA, but methyl substitution at other positions, especially at 7 and 12 positions, decreases the photocleavage efficiency for BA. This structurephotocleavage efficiency relationship match the gap between the highest occupied molecular orbital and lowest unoccupied molecular orbital (HOMO-LUMO) for these methyl substituted BAs [47]. 
Table 1: Relative DNA photocleavage efficiency expressed by $\mathrm{C}_{25}$ [47]

\begin{tabular}{lccr}
\hline Benz[a]anthracenes $(B A)$ & $C_{25}(\mu M)$ & Benzo[a]pyrene $(B a P)$ derivatives & $C_{25}(\mu M)$ \\
\hline BA & 18 & BaP & 6.0 \\
1-Methyl-BA & 60 & 1-Hydroxy-B[a]P & 0.6 \\
2-Methyl-BA & 74 & 3-Hydroxy-B[a]P & 2.5 \\
3-Methyl -BA & 34 & 6-Acetoxy-B[a]P & 1.3 \\
4-Methyl-BA & 12 & 7-Hydroxy-B[a]P & 0.1 \\
5-Methyl-BA & 13 & 9-Hydroxy-B[a]P & 1.3 \\
6-Methyl-BA & 20 & B[a]P-3,6-quinone & 3.9 \\
7-Methyl-BA & $\sim 100$ & B[a]P-1,6-quinone & 2.5 \\
7-Hydroxymethyl-BA & $\sim 100$ & B[a]P-7,8-dihydrodiol & 1.1 \\
8-Methyl-BA & 18 & & PAHs \\
9-Methyl-BA & 17 & Naphtahlene & $\mathrm{nd}$ \\
10-Methyl-BA & 12 & Anthracene & 8.3 \\
11-Methyl-BA & 42 & Chrysene & 5.2 \\
12-Methyl-BA & 93 & Pyrene & 51 \\
12-Hydroxymethyl-BA & $\sim 100$ & BA & 18 \\
7,12-Dithemyl-BA & $\sim 100$ & BaP & 6.0 \\
BA-7,12-dione & 11.8 & &
\end{tabular}

Mechanistic studies reveal that singlet oxygen, superoxide and other radicals intermediates, including possible PAH radicals, are involved in causing DNA single strand photocleavage by PAHs $[47,60,62,64]$. Both an oxygen-dependent and an independent pathway cause the DNA photocleavage. From PAH to PAH, the involvement of one or the other reactive species in DNA photocleavage can be different. In summary, the efficiency of lightinduced DNA cleavage by PAHs is closely related to the photochemical reaction of the PAHs and the presence of chemicals or solvents that affect the photochemical reaction or the production of reactive intermediates.

\section{Formation of 8-Hydroxyguanine (8-OHdG) Adduct}

It was reported that benzo[a]pyrene exposed to fluorescent light in mammalian cells induced 8-OHdG adduct [37]. Liu et al. reported that benzo[a]pyrene enhances the formation of 8OHdG formation by UVA radiation in calf thymus DNA and cultured cells [65]. The level of 8-OHdG adduct formed in cultured cells was much higher than that in calf thymus DNA. These results suggest that the metabolites of benzo[a]pyrene exhibit higher capability in induction of 8-OH-dG [65]. The subsequent study revealed that its metabolite, benzo[a]pyrene bay-region diolepoxide combined with UVA synergistically induced $8-\mathrm{OHdG}$ in a level about 25-fold higher than benzo[a]pyrene. The mechanistic study indicated that the formation of $8-\mathrm{OHdG}$ was mediated by reactive oxygen species [66].

\section{Other DNA Damage}

The phototoxicity and photomutagenicity of azulene was studied in human skin Jurkat T-cells by Comet assay. Azulene exposed to UVA light caused strand cleavage on DNA in the T-cell nucleus or pure $\Phi X 174$ plasmid DNA in solution [67].

\section{Formation of Lipid Peroxidation}

The authors are also interested in determining whether or not photoirradiation of PAHs can lead to induce lipid peroxidation. The approach is to perform the photoirradiation of a series of chrysene and its isomeric methylchrysenes and ethylchrysenes by UVA light in the presence of a lipid, methyl linoleate. Upon peroxidation, methyl linoleate is converted into the isomeric methyl linoleate 9- and 13-hydroperoxides, both in trans- and cisforms (Figure 3). We have previously reported the employment of methyl linoleate for study of lipid peroxidation induced by chrysene, 4-methylchrysene, 5methylchrysene, 1-ethylchrysene, 2-ethylchrysene, 3ethylchrysene, 4-ethylchrysene, and 5-ethylchrysene, concomitantly exposed to UVA light (unpublished data). The results indicate that all are capable of inducing lipid peroxidation (Figure 4). The results also indicate while 4and 5-ethylchryses induce lipid peroxidation at a level 
similar to that of chrysene, 1-, 2-, and 3-ethylchrysene are weaker than chrysene in induction of lipid peroxidation.

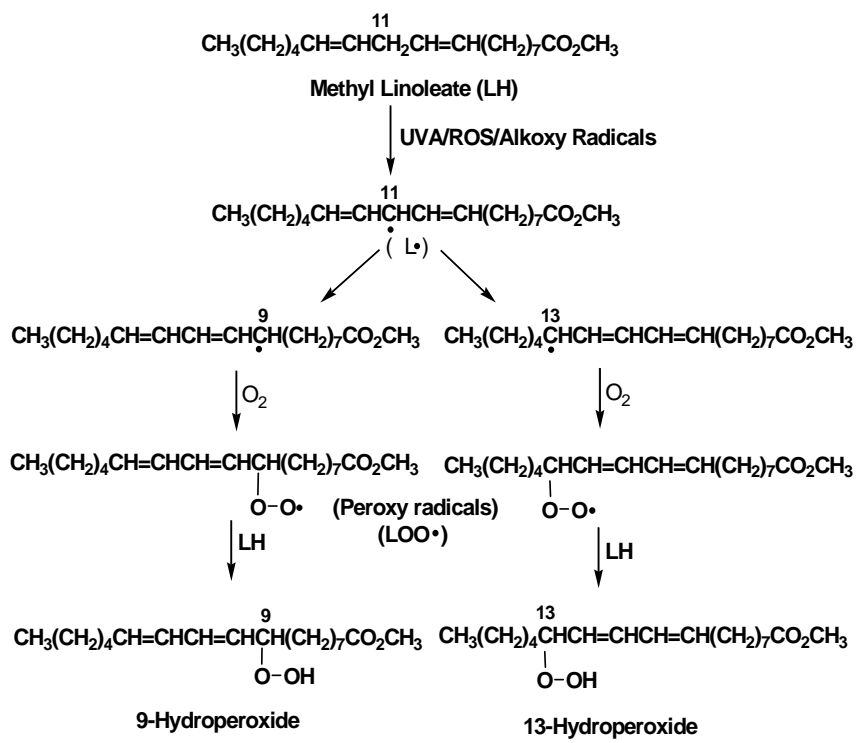

Figure 3: Peroxidation of methyl linoleate into the isomeric 9- and 13-hydroperoxides.

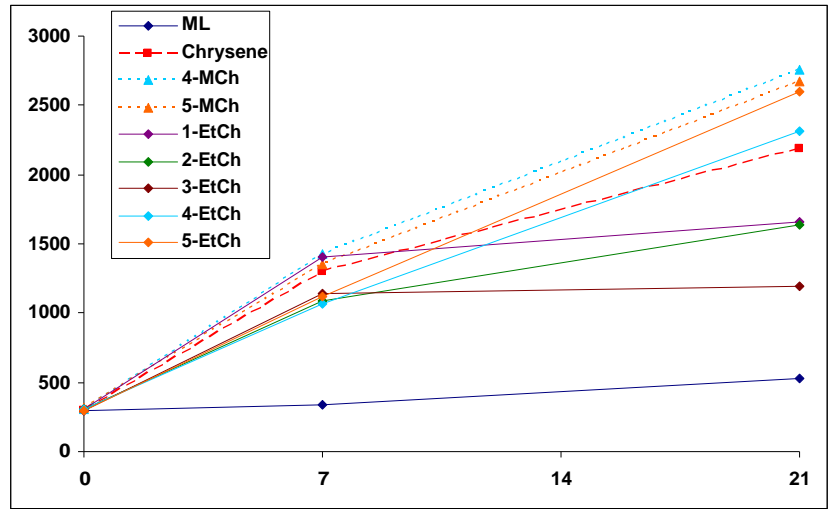

Figure 4: Induction of lipid peroxidation by photoirration of chrysene and its methylated and ethylated derivatives by UVA light.

\section{Conclusions and Perspectives}

Skin is a principal target organ on cancer induced by PAHs. For the Goeckerman therapy of psoriasis, coal tar is topically applied on the skin followed by UV light irradiation. This treatment has an increased risk of developing cutaneous cancers [68]. Roofers and highway asphalt workers also have a high risk to be exposed to both PAHs and light [69]. In the modern age we humans are in, the automobile exhaust emits PAHs. These PAHs in the air can be absorbed by skin. Since human skin is exposed to light, it is of particular importance and significance to investigate human health risks posed by exposure to the combination of PAHs and light.
Acknowledgement: This research was supported by the National Institutes of Health: NIH SCORE S06 GM08047, NIH-RCMI G12RR13459 and the US Army Research Office DAAD 1901-1-0733 to JSU.

\section{References}

1. Connell, D. W.; Hawker, D. W.; Warne, M. J.; Vowles, P. P.: Polycyclic aromatic hydrocarbons (PAHs). In Introduction into Environmental Chemistry (McCombs, K., and Starkweather, A. W., eds), 1997, pp. 205-217, CRC Press LLC, Boca Raton, FL.

2. Shaw, G. R.; Connell, D. W.: Prediction and monitoring of the carcinogenicity of polycyclic aromatic compounds (PACs). Rev. Environ. Contam. Toxic., 1994, 135, 1-62.

3. Dipple, A.: Polycyclic Aromatic Hydrocarbons and Carcinogenesis, American Chemical Society, Washington, DC., 1985.

4. Warshawsky, D.: Polycyclic aromatic hydrocarbons in carcinogenesis. Environ. Health Perspect., 1999, 107, 317-320.

5. Talaska, G.; Underwood, P.; Maier, A.; Lewtas, J.; Rothman, N.; Jaeger, M.: Polycyclic aromatic hydrocarnons (PAHs), nitro-PAHs and related environmental compounds: Biological markers of exposure and effects. Environ. Health. Perspect., 1996, 104, 701-908.

6. Harvey, R. G.: Polycyclic Aromatic Hydrocarbons, Wiley-VCH, New York, 1996.

7. Angerer, J.; Mannschreck, C.; Gundel, J.: Biological monitoring and biochemical effect monitoring of exposure to polycyclic aromatic hydrocarbons. Int. Arch. Occup. Environ. Health, 1997, 70, 365-377.

8. Jongeneelen, F. J.: Biological monitoring of environmental exposure to polycyclic aromatic hydrocarbons: 1-hydroxypyrene in urine of people. Toxicol. Lett., 1994, 72, 205-211.

9. IARC, Polynuclear aromatic compounds. Part I: Chemical, Environmental and Experimental Data, International Agency for Research on Cancer, Lyon, 1983.

10. National Toxicology Program, , US Department of Health and Human Services, 10th Report on Carcinogens. In 2002, pp. III-201-204, Integrated Laboratory Systems, Inc., Research Triangle Park, NC.

11. US Department of Health and Human Services, P. H. S., ATSDR, Toxicological Profile for Polycyclic Aromatic Hydrocarbons (PAHs), 1995, Atlanta.

12. Stevenson, J. L., and Von Haam, E. (1965) Carcinogenesis of benz $[a]$ anthracene and benzo[c]phenanthrene derivatives. Am. Ind. Hyg. Assoc. J. 1965, 26, 475-478.

13. Yang, S. K.; Silverman, B. D. (eds.): Polycyclic Aromatic Hydrocarbon Carcinogenesis: StructureActivity Relationships, CRC Press, Boca Raton, FL, 1988, Vols. I \& II.

14. Lesko, S. A.: Chemical carcinogenesis: benzopyrene 
system, Methods in Enzymology, 1984, 105, 539-550.

15. RamaKrishna, N. V. S.; Devanesan, P. D.; Rogan, E. G.; Cavalieri, E. L.; Jeong, H.; Jankowiak, R.; Small, G. J.: Mechanism of metabolic activation of the potent carcinogen 7,12-dimethylbenz[a]anthracene, Chem. Res. Toxicol. 1992, 5, 220-226.

16. Penning, T. M.; Burczynski, M. E.; Hung, C. F.; McCoull, K. D.; Palackal, N. T.; Tsuruda, L. S.: Dihydrodiol dehydrogenases and polycyclic aromatic hydrocarbon activation: generation of reactive and redox active o-quinones, Chem Res. Toxicol., 1999, 12, 1-18.

17. Yu, H.: Environmental Carcinogenic polycyclic aromatic hydrocarbons: photochemistry and phototoxicity. J. Environ. Sci. Health. Part C, Environ. Carcinog. \& Ecotox. Revs. 2002, C20, 149-83.

18. Kohn-Speyer, A. C.: Effect of ultra-violet radiation on the incidence of tar cancer in mice. Lancet, 1929, 217, 1305-1306.

19. Morton, J. J.; Luce-Clausen, E. M.; Mahoney, E. B.: Visible light and skin tumors induced with benzpyrene in mice. Cancer Res., 1942, 2, 256-260.

20. Morton, J. J.; Luce-Clausen, E. M.; Mahoney, E. B.: The effect of visible light on the development of tumors induced by benzpyrene in the skin of mice. Am. J. Roent. Rad. Ther., 1940, 43, 896-898.

21. Rusch, H. P.; Kline, B. E.; Baumann, C. A.: The nonadditive effect of ultraviolet light and other carcinogenic procedures. Cancer Res., 1942, 2, 183-188.

22. Santamaria, L.; Giordano, G. G.; Alfisi, M.; Cascione, F.: Effects of light on 3,4-benzpyrene carcinogenesis. Nature, 1966, 210, 824-825.

23. Swartz, R. C.; Ferraro, S. P.; Lamberson, J. O.; Cole, F. A.; Ozretich, R. J.; Boese, B. L.; Schults, D. W.; Behrenfeld, M.; Ankley, G. T.: Photoactivation and toxicity of mixtures of polycyclic aromatic hydrocarbon compounds in marine sediment. Environ. Toxicol. Chem., 1997, 16, 2151-57.

24. Pelletier, M. C.; Burgess, R. M.; Ho, K. T.; Kuhn, A.; McKinney, R. A.; Ryba, S. A.: Phototoxicity of individual polycyclic aromatic hydrocarbons and petroleum to marine invertebrate larvae and juveniles. Environ. Toxicol. Chem., 1997, 16, 2190-99.

25. Fernandez, M.; L'Haridon, J.: Influence of lighting conditions on toxicity and genotoxicity of various $\mathrm{PAH}$ in the newt in vivo. Mutat. Res., 1992, 298, 31-41.

26. Kagan, J.; Tuveson, R. W.; Gong, H. H.: The lightdependent cytotoxicity of benzo[a]pyrene: effect on human erythrocytes, Escherichia coli cells, and Haemophilus influenzae transforming DNA. Mutat. Res., 1989, 216, 231-42.

27. Arfsten, D. P.; Schaeffer, D. J.; Mulveny, D. C.: The effects of near ultraviolet radiation on the toxic effects of polycyclic aromatic hydrocarbons in animals and plants: A review. Ecotoxicol. Environ. Safety, 1996, 33, 1-24.

28. Landrum, P. F.; Giesy, J. P.; Oris, J. T.; Allred, P. M.: Photoinduced toxicity of polycyclic aromatic hydrocarbons to aqautic organisms. In Symposium on Oil Pollution of Freshwater (Vandermeulen, J. H.; Hrudey, S. E., eds), Pergamon, Ann Arbor, 1987, pp. 304-318.

29. Takeda, N.; Teranishi, K.; Hamada, K.; Mutagenicity of the sunlight-exposed sample of pyrene in Salmonella typhimurium TA98. Bull. Environ. Contam. Toxicol., 1984, 33, 410-417.

30. Okinawa, R. T.; Nickols, J. W.; Whaley, T. W.; Strniste, G. F.: 1-Nitropyrene: a mutagenic product induced by the action of near ultraviolet light on 1aminopyrene. Mutat. Res., 1986, 173, 93-98.

31. McCoy, E. C.; Hyman, J.; Rosenkranz, H. S.: Conversion of environmental pollutant to mutagens by visible light. Biochem. Biophys. Res. Comm., 1979, 89, 729-734.

32. Camalier, R. F.; Gantt, R.; Price, F. M.; Stephens, E. V.; Baeck, A. E.; Taylor, W. G.; Sanford, K. K.: Effect of visible light on benzo(a)pyrene binding to DNA of cultured human skin epithelial cells. Cancer Res., 1981, 41, 1789-1793.

33. Fernandez, M.; L'Haridon, J.: Influence of lighting conditions on toxicity and genotoxicity of various PAH in the newt in vivo. Mutat. Res., 1992, 298, 31-41.

34. Kagan, J.; Kagan, E.: The toxicity of benzo[a]pyrene and pyrene in the mosquito Aedes aegypti in the dark and in the presence of ultraviolet light. Chemosphere, 1986, 15, 243-251.

35. Kagan, J.; Stokes, A.; Gong, H.-H.; Tuveson, R. W.: Light-dependent cytotoxicity of fluoranthene: Oxygen-dependent membrane damage. Chemosphere, 1987, 16, 2417-2422.

36. Kagan, J.; Tuveson, R. W.; Gong, H.-H.: The lightdependent cytotoxicity of benzo[a]pyrene: Effect of human erythrocytes, Escherichia coli cells, and haemophilus influenzae transforming DNA. Mutat. Res., 1989, 216, 231-242.

37. Mauthe, R. J.; Cook, V. M.; Coffing, S. L.; Baird, W. M.: Exposure of mammalian cell cultures to benzo[a]pyrene and light results in oxidative DNA damage as measured by 8-hydroxydeoxyguanosine formation. Carcinogenesis, 1995, 16, 133-137.

38. Pfaum, M.; Boiteux, S.; Epe, B.: Visible light generates oxidative DNA base modification in high excess of strand breaks in mammalian cells. Carcinogenesis, 1994, 15, 297-300.

39. Sinha, B. K.; Chignell, C. F.: Binding of anthracene to cellular macromolecules in the presence of light. Photochem. Photobiol., 1983, 37, 33-37.

40. Tuveson, R. W.; Wang, G. R.; Wang, T. P.; Kagan, J.: Light-dependent cytootoxic reactions of anthracene. Photochem. Photobiol., 1990, 52, 993-1002.

41. Utsumi, H.; Elkind, M. M.: Photodynamic cytotoxicity of mammalian cells exposed to sunlight-sumulated near ultraviolet light in the presence of the carcinogen 7,12dimethylbenz[a]anthracene. Photochem. Photobiol., 1979, 30, 271-278.

42. White, G. L.; Fu, P. P.; Heflich, R. H.: Effect of nitro 
substitution on the light-mediated mutagenicity of polycyclic aromatic hydrocarbons in Samonella typhimurium TA 98. Mutat. Res., 1985, 144, 1-7.

43. Schmidt, R.; Schaffner, K.; Trost, W.; Brauer, H.-D.: Wavelength dependent and dual photochemistry of the endoperoxides of anthracene and 9,10dimethylanthracene. J. Phys. Chem., 1984, 88, 956-958.

44. Sigman, M. E.; Zingg, S. P.; Pagni, R. M.; Burns, J. H.: Photochemistry of anthracene in water. Tetrahedron Lett., 1991, 32, 5737-5740.

45. Katz, M.; Chan, C.; Tosine, H.; Sakuma, T.: Relative rates of photochemical and biological oxidation (in vitro) of polynuclear aromatic hydrocarbons. In Polynuclear Aromatic Hydrocarbons. Third International Symposium on Chemistry and Biology - Carcinogenesis and Mutagenesis (Jones, P., and Leber, P., eds), Ann Arbor Science, Ann Arbor. 1979, pp. 171-190.

46. Sigman, M. E.; Schuler, P. F.; Ghosh, M. M.; Dabestani, R.: Mechanism of pyrene photochemical oxidation in aqueous and surfactant solutions. Environ. Sci. Technol., 1998, 32, 3980-3885.

47. Dong, S.; Fu, P. P.; Shirsat, R. N.; Hwang, H.-M.; Leszczynski, J.; Yu, H.: UVA light-induced DNA cleavage by isomeric methylbenz[a]anthracenes. Chem. Res. Toxicol., 2002, 15, 400-409.

48. Fox, M. A.; Olive, S.: Photooxidation of anthracene on atmospheric particulate matter. Science, 1979, 205, 582-583.

49. Yu, H.; Yan, J.; Jiao, Y.; Fu, P.: "Photochemical Reaction of 7,12-dimethylbenz[ $a]$ anthracene and formation of DNA covalent adducts", Int. J. Environ. Res. Public Health, 2005, 2(1), 114-122.

50. Wood, J. L.; Barker, C. L.; Grubbs, C. J.: Photooxidation products of 7,12-dimethylbenz[a]anthracene. Chem.-Biol. Interact., 1979, 26, 339-347.

51. Strniste, G. F.; Martinez, E.; Martinez, A. M.; Brake, R. J.: Photo-induced reactions of benzo[a]pyrene with DNA in vitro. Cancer Res., 1980, 40, 245-252.

52. Pelletier, M. C.; Burgess, R. M.; Ho, K. T.; Kuhn, A.; McKinney, R. A.; Ryba, S. A.: Phototoxicity of individual polycyclic aromatic hydrocarbons and petroleum to marine invertebrae lavae and juveniles. Environ. Toxicol. Chem., 1997, 16, 2190-2199.

53. Swartz, R. C.; Ferraro, S. P.; Lamberson, J. O.; Cole, F. A.; Ozretich, R. J.; Boese, B. L.; Schults, D. W.; Behrenfeld, M.; Ankley, G. T.: Photoactivation and toxicity of mixtures of polycyclic aromatic hydrocarbon compounds in marine sediment. Environ. Toxicol. Chem., 1997, 16, 2151-2157.

54. Yan, J.; Wang, L.; Fu, P. P.; Yu, H.: Photomutagenicity of sixteen polycyclic aromatic hydrocarbons from the US EPA's priority pollutants. Mutat. Res., 2004, 557, 99-108.

55. Tetreault, N.; Muthyala, R. S.; Liu, R. S. H.; Steer, R. P.: Control of the photophysical properties of polyatomic molecules by substitution and solvation: The second excited singlet state of azulene, J. Phys. Chem. A, 1999, 103, 2524-2531.
56. Wang, L.; Yan, J.; Fu, P. P.; Parekh, K. A.; Yu. H.: Photomutagenicity of cosmetic ingredient chemicals azulene and guaiazulene. Mutat. Res., 2003, 530, 19-26.

57. Ts'o, P. O. P.; Lu, P.: Interaction of nucleic acids, II. Chemical linkage of the carcinogenic 3,4-benzpyrene to DNA induced by photoradiation. Proc. Nat. Acad. Sci. USA., 1964, 51, 272-280.

58. Blackburn, G. M.; Taussig, P. E.: The photocarcinogenicity of anthracene: Photochemical binding to deoxyribonucleic acid in tissue culture. Biochem. J., 1975, 149, 289-291.

59. Utsumi, H.; Kitani, H., M., C.-L. C.; Elkind, M. M.: 7,12-Dimethylbenz[a]anthracene plus near-u.v. light initiates DNA damage and repair in Chinese hamster cells. Carcinogenesis, 1987, 8, 1439-1444.

60. Dong, S.; Hwang, H.-M.; Shi, X.; Holloway, L.; Yu, H.: UVA-induced DNA single strand cleavage by 1hydroxypyrene and formation of covalent adducts between DNA and 1-hydroxypyrene. Chem. Res. Toxicol., 2000, 13, 585-593.

61. Dong, S.; Fu, P. P.; Hwang, H.-M.; Yu, H.: Effects of histidine on light-induced DNA single strand cleavage by selected polycyclic aromatic hydrocarbons. Polycycl. Arom. Compd., 2002, 22, 451-458.

62. Dong, S.; Hwang, H.-M.; Harrison, C.; Holloway, L.; Shi, X.; Yu, H.: UVA light-induced DNA cleavage by selected polycyclic aromatic hydrocarbons. Bull. Environ. Contam. Toxicol., 2000, 64, 467-474.

63. Dong, S.; Wang, S.; Stewart, G.; Hwang, H.-M.; Yu, H.: Effect of solvents and biologically relevant ions on the light-induced DNA cleavage by polycyclic aromatic hydrocarbons. Int. J. Mol. Sci., 2002, 3, 934-944.

64. Yu, H.; Dong, S.; Fu, P. P.; Hwang, H.-M.: UVA light-induced DNA single strand cleavage by hydroxybenzo[a]pyrenes. Polycycl. Arom. Compd., 2002, 22, 861-870.

65. Liu, Z.; Lu, Y.; Rosenstein, B.; Lebwohl, M.; Wei, H.: Benzo[a]pyrene enhances the formation of 8-hydroxy2'-deoxyguanosine by carcinoma cells. Biochemistry, 1998, 37, 10307-10312.

66. Gao, D.; Luo, Y.; Guevara, D.; Wang, Y.; Rui, M.; Goldwyn, B.; Lu, Y.; Smith, E. C. A.; Lebwohl, M.; Wei, H.: Benzo[a]pyrene and its metabolites combined with ultraviolet A synergistically induce 8-hydroxy-2'deoxyguanosine via reactive oxygen species. Free Rad. Biol. Med., 2005, 39, 1177-1183.

67. Wang, L.; Yan, J.; Cohly, H.; Hwang, H.-M.; Wang, S.; Fu, P. P.; Yu H.: Photo-acute toxicity and genotoxicity of azulene on human Jurkat T-cells, Mutat. Res., 2004, 562(1-2), 143-150.

68. Stern, R. S.; Zierler, S.; Parrish, J. A.: Skin carcinoma in patients with psoriasis treated with topical tar and artificial ultraviolet radiation. Lancet. 1980, 2, 732-733.

69. Reed, L. D.; Liss, G. M.: PAH exposure among pitch and asphalt roofing workers, Polynuclear Aromatic Hydrocarbons: Mechanisms, Method, and Metabolism, (Cooke and Dennis Ed.), Bartelle Press, Columbus, 1985, pp 1089-1095. 